\title{
English Language Anxiety and its impact on the Communicative Performance of the Learners w.r.t the Students of B-Schools in Delhi NCR, India
}

\author{
Yusuf Mehdi, Shravan Kumar
}

\begin{abstract}
English is the co-official language of India and the diversified nature of the country makes it imperative for the people to know English language even to communicate within the country. There are more than 30 regional languages spoken in India and English has become a kind of link language. In addition to this, English, in India, is required to get good jobs and promotions. This demand makes the students anxious and leads to English Language anxiety. In the Indian context, English also determines, to a large extent, the status of the people. People who speak good English are considered more educated and intelligent. English Language anxiety has a very debilitating effect on the performance of the students especially in spoken English. When the students are not able to perform well in terms of speaking; they become more anxious and lose confidence. This lack of confidence further sways them away from language learning. It has been observed that such students start refraining from even participating in conversations and discussions. The present paper aims at investigating the relationship between English language anxiety and the communicative performance of the learners. Finally, the study will make pedagogical recommendations in order to alleviate the English language anxiety of the students.
\end{abstract}

Keywords: Language Anxiety; Foreign Language; Second Language, Performance; Communication Skills.

\section{INTRODUCTION}

English language holds a very important place in the world. It has indeed become a link language which makes it possible for the people around the globe to communicate with each other. In the Indian context also, English plays a vital role. India is a diverse country with more than 30 regional languages spoken across. In order to communicate effectively in the country itself, a link language is required because learning all regional languages is practically not feasible even for the most versatile language learners. English, thus, fulfils the requirement, since India is the second largest English-speaking country next to the US. According to an article 'English or Hinglish - What will India Choose' by Zareer Masani published in the Magazine, BBC on 27th November 2012, around 125 million people in India speak English. It would not be wrong to say that English is indeed the lingua franca of India. Had it been only for the purpose of communication, English language learning would be fine but in India, people have started associating English

Revised Manuscript Received on November 11, 2019.

* Correspondence Author

Mr. Yusuf Mehdi, Research Scholar, AIESR, Amity University, Noida Noida. language with status and level of education. People who can speak good English are considered more intelligent and educated. English language is seen as a status symbol these days in India. In addition to this, English is also required to get good jobs especially in the corporate world today. For the students of professional courses, English is a passport to high paying jobs in the corporate. Students, who are not good at English Language communication especially at speaking, find it difficult to get through the interview process. There have been many research which conclude that even the students with valid degrees are not able to get good jobs because of poor English language communication skills. Almost in all schools in India English is taught from the very beginning and even in Graduation and Post-Graduation, students have to go through various Communication skills courses which focus on helping students learn business English.

Language anxiety is something that is experienced by all the learners of the new language. According to Campbell and Ortiz, all the Second language learners and the foreign language learners experience anxiety to a certain extent. The anxiety, as indicated by Horwitz et. al. is mostly related to poor performance in the foreign language, especially in speaking skills. MacIntyre and Gardner define language anxiety as "the apprehension experienced when a situation requires the use of a SL/FL with which the individual is not fully proficient, this apprehension being characterised by 'derogatory self-related cognitions... feeling of apprehension and physiological responses such as increased heart rate" (MacIntyre \& Gardner 1993:5). "The essence of second/foreign language learning is the communication of personally meaningful and conversationally appropriate messages through unfamiliar syntactic, semantic, and phonological systems" (Horwitz, 1995, p. 573), therefore many second/foreign language (SL/FL) learners find the basic requirements of SL/FL learning inherently stressful (Horwitz, 1995). There has been an exhaustive research on the subject and almost all the research conclude that language anxiety cast a negative impact on the students in terms of their emotional reactions since they were dealing with a totally new culture and language. Although, there are a few studies that hint upon anxiety facilitating language learning by motivating the learners to know more about the new language, yet the findings of the majority of studies related to anxiety and language learning have been uniform and consistently indicate a moderate negative relationship between language learning anxiety and performance 
(Bailey, 1983; Frantzen and Magnan, 2005; Gregersen, 2003; Spielmann and Radnofsky, 2001).

Horwitz et al. in 1986 conducted a ground breaking study in which a scale was formulated to measure the foreign language anxiety - Foreign Language Classroom Anxiety Scale (FLAS) which has been extensively used to measure the anxiety in the language learners.

\section{BACKGROUND}

English language is the most prominent language today in the world since it serves the purpose of a link language between the people of different places. In the Indian context too, English language holds a lot of importance. In India, there are more than 30 regional languages spoken in different parts and because of globalisation all these parts have merged into one. The Constitution of India designates Hindi, as well as English as the official language of the Government of India. During the British Rule, English was used for purposes at the Federal level. The Indian constitution adopted in 1950 envisaged that Hindi would be gradually phased in to replace English over a fifteen-year period, but gave the Parliament the power to, by law, provide for the continued use of English even thereafter. (https://en.wikipedia.org/wiki/Languages_with_official_stat us in India).

The rampant globalisation has made English the language of international communication. The non-English speaking countries, thus, have no choice but to become more receptive to English language. India is no exception in this race and has to make the Indian students adaptable both at National and International levels. To cater to this requirement, India needs to train the students in communicative competence in English language

The use of English language has reduced in the Administration but it has been very rapidly increasing in education and in the private sectors. The higher education in India is imparted completely in the English language. For this reason, English is introduced as a compulsory subject right from the kindergarten to the Post Graduate level. The people need to understand English language to do business, to do diplomatic jobs and private sector jobs and to pursue higher studies. However, it is quite unfortunate that most of the people in India are still not able to use this language effectively. The professional graduates with valid degrees are not able to get good jobs just because of their poor communication skills. Communication skills as such have got nothing to do with any particular language but in today's world where English has gained a lot of prominence, when we talk about communication skills, especially in Indian context, it is English Language communication skills. The students, most of them, go through communication skills courses right from their schooling but still are incapable of using English language effectively. The major problem, according to many research, is the anxiety which the students feel while learning English language. It has been observed that language learning anxiety has a very debilitating effect on the performance of the learners. The learners become anxious and that tends to drag them backwards. The performance of the students, especially spoken, suffers a lot because of the language anxiety. Research in EFL has been trying to investigate the psychological factors that affect language acquisition and learning. There are various such factors which affect the performance of the learners in terms of success or failure in language learning. One of the major factors is 'anxiety' - language learning anxiety. The term 'anxiety' has been explained in dictionaries as "a state of apprehensive uneasiness or nervousness usually over an impending or anticipated ill (Meriam-Webster). Anxiety can be further divided into two categories - Trait Anxiety and State Anxiety. Trait anxiety may be defined as "a relatively stable tendency to exhibit anxiety in a large variety or circumstances" whereas State anxiety is "a situation-specific trait anxiety, that is, an individual suffering from state anxiety will manifest a stable tendency to exhibit anxiety but only in certain situations" (Phillips, 1992, p. 14).

Language learning anxiety is a kind of 'state anxiety', according to Brown (2000). Moreover, Horwitz and Cope (1986) believe that language anxiety is not same as the general anxiety. Language anxiety is a State Anxiety as it takes place only when the learners have to use this language in public. Horwitz and Cope identified the following three components of language anxiety:

a. Communication apprehension that arises from the inability of the learners adequately express thoughts and ideas

b. Apprehension about negative social evaluation; and

c. Apprehension over academic evaluation i.e. Test Anxiety The Foreign Language Classroom Anxiety Scale (FLCAS) was designed considering the above-mentioned components. The scale was constructed based on clinical experience of the Horwitz and team; self-reports from students, and the results collected from other such instruments. The original FLCAS scale had total 33 items and was based on 5-point Likert scale. According to FLCAS, the higher the score, the higher will be the anxiety. Reliability of the scores obtained from the instrument based on data collected from 108 respondents was quite high with Cronbach's alpha of .93 (Horwitz, 1986). Apart from this, test-retest reliability which was carried out with a sample of 78 participants spanned over a period of eight weeks and was ascertained to be $r=0.83(p<0.01)$ (Horwitz, 1991).

\section{LITERATURE REVIEW}

There has been a lot of research in the field of second language learning (SLA) with the researchers exploring and investigating very minute aspects of language learning. In the process of investigating the finer aspects of SLA, the researchers have devised a number of instruments and scales to measure and record the attitude, motivation, anxiety, and interest of the learners. Researchers keep trying to devise ways to help the learners acquire or learn second language as naturally and effectively as possible. The finer aspects and nuances of languages and language learning approaches are thoroughly assessed. One of such aspects is 'Language Anxiety'. There has been a rise in awareness in the language teachers and psychologists about the negative effects of Language Anxiety, leading to a number of research about this phenomenon (Gregersen, 2006). The introduction of various instruments to measure anxiety has further encouraged the researchers to carry out research in the field.

The instrument constructed by Horwitz et. al. (1986) to measure the anxiety of the language learners was called Foreign Language Classroom Anxiety Scale (FLCAS) and it was very extensively used by many researchers in order to assess and find out the language learning anxiety of the learners 
in various regions and for different languages. Many researchers also reviewed the scale in order to find its reliability and consistency for different languages. Aida (1994) reviewed the scale by using the adapted version of the scale on the students of Japanese. The results of the adapted FLCAS seemed to be highly reliable at measuring the anxiety levels of the learners in learning Japanese.

Zhao (2007) attempted the similar review and used the Chinese version of FLCAS to measure anxiety levels of Chinese students in learning English as a foreign language. The adapted version in this case covered all the 33 items of the original FLCAS; however, no reliability measures were reported from the study.

Yet another study conducted in the same field concluded that language anxiety impacted the learners in different ways according to the kind of instructions the learners experienced (Saito and Samimy, 1996). Various different aspects were studied but the final observation was that the language anxiety was among the top predictors of performance in language learners.

\section{THE STUDY}

The current paper aims at investigating the effects of language learning anxiety on the performance of the learners especially the oral performance. The learners in the study are the PG level students of B-Schools in Delhi NCR (National Capital Region). The students of management institutions are taught Business Communication courses. The aim of these courses is to make the students corporate ready by helping them learn standard and effective Business English. Data was collected by using a modified version of a standard scale called Foreign Language Classroom Anxiety Scale (FLCAS) originally designed by Horwitz.

\section{Sample}

The sample for the investigation included 118 respondents who were students of Post Graduate Diploma in Management (PGDM) at a reputed B-School in Delhi NCR. The sample included 73 males and 45 females.

\section{Instrument:}

The scale used in the study was a modified version of Horwitz's "Foreign Language Classroom Anxiety Scale (FLCAS)". The scale was conformed to 5-point Likert scale that had a range from strongly agree to strongly disagree (Table 1). Internal consistency of the FLCAS is already proven and it also has a good reliability and validity. The modified scale was checked for internal consistency and reliability by applying Cronbach's Alpha. The value of $\alpha$ for the scale after modification was 0.94 .

\begin{tabular}{|c|c|c|c|c|}
\hline $\begin{array}{c}\text { Strongly } \\
\text { Agree }\end{array}$ & Agree & Neutral & Disagree & $\begin{array}{c}\text { Strongly } \\
\text { Disagree }\end{array}$ \\
\hline 5 & 4 & 3 & 2 & 1 \\
\hline
\end{tabular}

Table 1: Input values for the Scale

\section{Reliability Statistics}

\begin{tabular}{|c|c|}
\hline Cronbach's Alpha & N of items \\
\hline 0.943 & 27 \\
\hline
\end{tabular}

Table2: Reliability Statistics

The respondents were from different social, economic, and linguistic background. The mother tongue of some of the respondents was different and the level of proficiency in English language was also quite varied. Nevertheless, the students did have the basic understanding of English and therefore the questionnaire was administered in English language to them. The focus of the questionnaire was to record the responses of the students to assess the language learning anxiety in them. 27 items were included in the questionnaire for the same.

\section{Research Questions:}

1. Does English language anxiety impact the communicative performance of the B-School students?

2. Does English language anxiety affect the oral performance of the students of B-Schools?

\section{Questionnaire Construction}

The PG level students of a B-School in NCR were asked to respond to the questionnaire based on FLCAS by Horwitz. The respondents had to record their responses on a 5-point Likert scale ranging from Strongly Agree to Strongly Disagree. The items in the scale were related to language anxiety and the aim of the questionnaire was to record the responses related to English Language anxiety experienced by the second language learners. The Foreign Language Class Anxiety Scale (FLCAS) is a set of 33 test items in which respondents are asked to rank on the Likert scale of 5-points. Numerical index for a number of responses are calculated. These indices in turn are combined to yield a composite index. For the present study, the FLCAS was modified for the management PG students with total 27 Questions. 
English Language Anxiety and its impact on the Communicative Performance of the Learners w.r.t the Students of B-Schools in Delhi NCR, India

The modified FLCAS was administered to PG level students of a management course. These students are expected to have a good level of proficiency in English language to be able to become effective managers in the corporate and it is assumed that these students would have reasonably good command over spoken English. The scale aims at finding out whether

\section{Figure 1: The Modified FLCAS adapted for the study}

\section{Sub-Constructs:}

1. Communication Apprehension: the language anxiety impacts the communicative performance of the students in the class and if yes which aspect is affected the maximum. To investigate further the modified FLCAS was administered to 118 students of a B-School in Delhi NCR. \begin{tabular}{|c|l|} 
S. No. & \\
& \\
\hline I & I never feel quite sure of myself when I am speaking publicly in English Language. \\
\hline 2 & I don't worry about making mistakes while speaking in English. \\
\hline 3 & I tremble when I know that I am going to be called to speak publicly in English. \\
\hline 4 & It frightens me when I don't understand what the teacher is saying in English. \\
\hline 5 & I wouldn't bother me if I have to attend more English language training classes. \\
\hline 6 & During the English language training classes I often think of things which are not rel \\
\hline 7 & I keep comparing me with other students when it comes to speaking English. \\
\hline 8 & I am usually at ease when I have oral presentations in the class in English. \\
\hline 9 & I start to panic when I have to speak extemporarily in English. \\
\hline 10 & I worry about the consequences of not being able to learn English language. \\
\hline 11 & I don't understand why some people get so upset when it comes to give a presentation \\
\hline 12 & When I am asked to speak in English in the class, I forget even the things which I an \\
\hline 13 & I am scared to volunteer in my English language training class. \\
\hline 14 & I would not be nervous speaking in English with the native speakers. \\
\hline 15 & I get upset when I don't understand what the teacher is correcting. \\
\hline 16 & Even if I am well prepared, I feel anxious about presenting in English language. \\
\hline 17 & I often feel like not going to English Language training classes. \\
\hline 18 & I feel confident when I speak in English in the class. \\
\hline 19 & I am afraid that the language teacher will correct all my mistakes. \\
\hline 20 & I can feel my heart pounding when I am going to be called to speak in English publicly. \\
\hline 21 & The more I study about English language rules and structures, the more confused I g \\
\hline 22 & I don't feel pressure to prepare for a presentation to be delivered in English. \\
\hline 23 & I always feel that other students speak better English than me. \\
\hline 24 & I feel very self-coscious in speaking in English in the class. \\
\hline 25 & English language training class moves so quickly, I worry about getting left behind. \\
\hline 26 & I feel more tense and nervous in the language class than in my other classes. \\
\hline 27 & I get nervous and confused while giving a presentation in English language. \\
\hline & \\
\hline
\end{tabular}

Items \# 1, 4, 9,14, 15, 18, 24, 27

2. Test Anxiety:

Items \# 3,5,6, 8, 10, 11, 12, 16, 17, 20, 21, 22, 25, 26

3. Fear of Negative Evaluation:

Items \# 2, 7, 13, 19, 23

\section{Short profile of the respondents:}

Total respondents:

118

Males: $\quad 73$

Females:

45

Age:

20-23 Years

PG Year:

Ist year and IInd Year

Course:

Post Graduate Diploma in Management (PGDM, equivalent to MBA)

\section{ANALYSIS}

"It is quite controversial and confusing if the scale can be

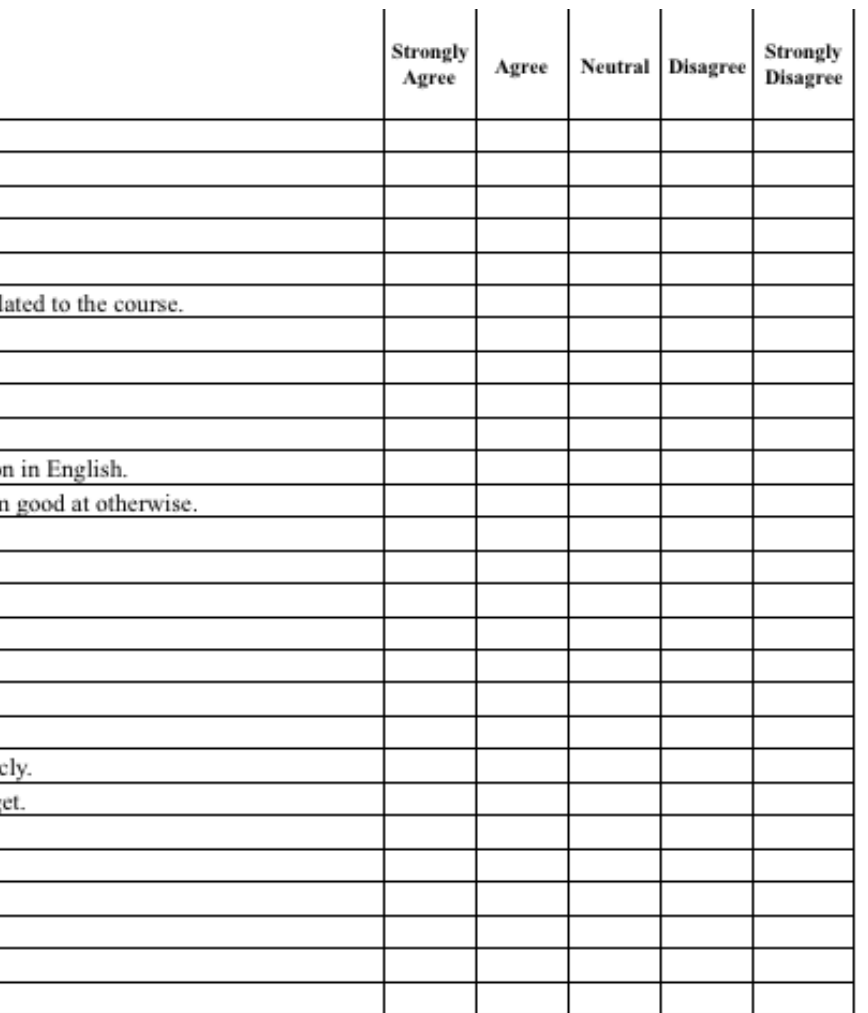

used to represent human attitudes; moreover, the Likert data is ordinal rather than interval" (Burns, 2000, p. 560). Furthermore, Likert scale indicates positive, neutral, and negative points only. Keeping all these points in mind, the statistical analysis was not carried out.

Qualitative comparisons were carried out on the basis of the averages of the obtained means. The responses of the students were, first transformed into numerical values in conformation with the Likert scale; then the means and the standard deviation values were calculated.

\section{DISCUSSION AND RESULTS}

\section{A. Communication Apprehension:}

The respondents, the PG level students of B-Schools, become very nervous and anxious when they are required to speak in English publicly. They clearly face Communication anxiety when it comes to speaking in English. The responses in the Table 3 clearly suggest that the students feel anxious whenever they are required to speak English publicly. In Anxiety Item No. 1, around $46 \%$ students Strongly Agree that they never feel quite sure of themselves when they speak in English language publicly. $14 \%$ agree to the same statement. According to Item Nos. 4 and 15, as many as $50 \%$ 
students agree that they get frightened when they don't understand what the teacher says in English language classes. While $64 \%$ students accept that they feel upset when they are not able to understand the instructions given by teachers in English. The fear of not understanding the teachers' instructions further strengthen the notion that these students are very anxious. In item no. 9, 46\% students agree while 22 $\%$ students strongly agree that they start to panic when they have to speak extemporarily in English. In item no. 14, hardly $7 \%$ students strongly agree and $10 \%$ students agree that they don't feel nervous when they talk in English the native speakers of English. however, $53 \%$ students accept to be nervous in this situation. Hardly 5-6\% students feel confident while speaking in English language classes. This shows the high level of anxiety experienced by the Indian B-School students when it comes to English language learning. The responses to the Items nos. 18, 24 and 27 clearly state that the students are very nervous and anxious when they are required to give presentation in the class in English language.

On the basis of above discussion, it can be inferred that students of PG classes in B-Schools feel a high level of Communication anxiety especially when they are required to speak publicly.

\section{Frequency distribution table:}

\begin{tabular}{|c|c|c|c|c|c|}
\hline \multicolumn{6}{|c|}{ Anxiety1 } \\
\hline & & Frequency & Percent & Valid Percent & $\begin{array}{l}\text { Cumulative } \\
\text { Percent }\end{array}$ \\
\hline Valid & $\begin{array}{l}\text { Strongly Agree } \\
\text { Agree } \\
\text { Neutral } \\
\text { Disagree } \\
\text { Strongly Disagree } \\
\text { Total }\end{array}$ & $\begin{array}{r}17 \\
54 \\
31 \\
9 \\
7 \\
118\end{array}$ & \begin{tabular}{r|}
14.4 \\
45.8 \\
26.3 \\
7.6 \\
5.9 \\
100.0
\end{tabular} & $\begin{array}{r}14.4 \\
45.8 \\
26.3 \\
7.6 \\
5.9 \\
100.0\end{array}$ & $\begin{array}{r}14.4 \\
60.2 \\
86.4 \\
94.1 \\
100.0\end{array}$ \\
\hline \multicolumn{6}{|c|}{ Anxiety4 } \\
\hline Valid & $\begin{array}{l}\text { Strongly Agree } \\
\text { Agree } \\
\text { Neutral } \\
\text { Disagree } \\
\text { Strongly Disagree } \\
\text { Total }\end{array}$ & $\begin{array}{r}21 \\
38 \\
25 \\
19 \\
15 \\
118\end{array}$ & \begin{tabular}{r|}
17.8 \\
32.2 \\
21.2 \\
16.1 \\
12.7 \\
100.0
\end{tabular} & $\begin{array}{r}17.8 \\
32.2 \\
21.2 \\
16.1 \\
12.7 \\
100.0\end{array}$ & $\begin{array}{r}\mathbf{1 7 . 8} \\
\mathbf{5 0 . 0} \\
\mathbf{7 1 . 2} \\
\mathbf{8 7 . 3} \\
\mathbf{1 0 0 . 0}\end{array}$ \\
\hline \multicolumn{6}{|c|}{ Anxiety9 } \\
\hline Valid & $\begin{array}{l}\text { Strongly Agree } \\
\text { Agree } \\
\text { Neutral } \\
\text { Disagree } \\
\text { Strongly Disagree } \\
\text { Total }\end{array}$ & $\begin{array}{r}26 \\
55 \\
18 \\
13 \\
6 \\
118\end{array}$ & \begin{tabular}{r|}
22.0 \\
46.6 \\
15.3 \\
11.0 \\
5.1 \\
100.0
\end{tabular} & $\begin{array}{r}22.0 \\
46.6 \\
15.3 \\
11.0 \\
5.1 \\
100.0\end{array}$ & $\begin{array}{r}22.0 \\
68.6 \\
83.9 \\
94.9 \\
100.0\end{array}$ \\
\hline \multicolumn{6}{|c|}{ Anxiety14 } \\
\hline Valid & $\begin{array}{l}\text { Strongly Agree } \\
\text { Agree } \\
\text { Neutral } \\
\text { Disagree } \\
\text { Strongly Disagree } \\
\text { Total }\end{array}$ & $\begin{array}{r}9 \\
12 \\
33 \\
22 \\
42 \\
118\end{array}$ & \begin{tabular}{r|}
7.6 \\
10.2 \\
28.0 \\
18.6 \\
35.6 \\
100.0
\end{tabular} & \begin{tabular}{r|}
7.6 \\
10.2 \\
28.0 \\
18.6 \\
35.6 \\
100.0
\end{tabular} & $\begin{array}{r}7.6 \\
17.8 \\
45.8 \\
64.4 \\
100.0\end{array}$ \\
\hline
\end{tabular}


English Language Anxiety and its impact on the Communicative Performance of the Learners w.r.t the Students of B-Schools in Delhi NCR, India

\begin{tabular}{|c|c|c|c|c|c|}
\hline Valid & $\begin{array}{l}\text { Strongly Agree } \\
\text { Agree } \\
\text { Neutral } \\
\text { Disagree } \\
\text { Strongly Disagree } \\
\text { Total }\end{array}$ & $\begin{array}{r}29 \\
46 \\
7 \\
23 \\
13 \\
118\end{array}$ & $\begin{array}{r}24.6 \\
39.0 \\
5.9 \\
19.5 \\
11.0 \\
100.0\end{array}$ & $\begin{array}{r}24.6 \\
39.0 \\
5.9 \\
19.5 \\
11.0 \\
100.0\end{array}$ & $\begin{array}{r}24.6 \\
63.6 \\
69.5 \\
89.0 \\
100.0\end{array}$ \\
\hline \multicolumn{6}{|c|}{ Anxiety18 } \\
\hline Valid & $\begin{array}{l}\text { Strongly Agree } \\
\text { Agree } \\
\text { Neutral } \\
\text { Disagree } \\
\text { Strongly Disagree } \\
\text { Total }\end{array}$ & $\begin{array}{r}2 \\
4 \\
18 \\
55 \\
39 \\
118\end{array}$ & \begin{tabular}{r|}
1.7 \\
3.4 \\
15.3 \\
46.6 \\
33.1 \\
100.0
\end{tabular} & \begin{tabular}{r|}
1.7 \\
3.4 \\
15.3 \\
46.6 \\
33.0 \\
100.0
\end{tabular} & $\begin{array}{r}1.7 \\
5.1 \\
20.4 \\
67 \\
100\end{array}$ \\
\hline \multicolumn{6}{|c|}{ Anxiety24 } \\
\hline \multirow[t]{2}{*}{ Valid } & $\begin{array}{l}\text { Strongly Agree } \\
\text { Agree } \\
\text { Neutral } \\
\text { Disagree } \\
\text { Strongly Disagree } \\
\text { Total }\end{array}$ & $\begin{array}{r}42 \\
32 \\
25 \\
13 \\
6 \\
118\end{array}$ & $\begin{array}{r}35.6 \\
27.1 \\
21.2 \\
11.0 \\
5.1 \\
100.0\end{array}$ & $\begin{array}{r}35.6 \\
27.1 \\
21.2 \\
11.0 \\
5.1 \\
100.0\end{array}$ & $\begin{array}{r}35.6 \\
62.7 \\
83.9 \\
94.9 \\
100.0\end{array}$ \\
\hline & \multicolumn{4}{|c|}{ Anxiety27 } & \\
\hline Valid & $\begin{array}{l}\text { Strongly Agree } \\
\text { Agree } \\
\text { Neutral } \\
\text { Disagree } \\
\text { Strongly Disagree } \\
\text { Total }\end{array}$ & $\begin{array}{r}28 \\
54 \\
12 \\
12 \\
12 \\
118\end{array}$ & \begin{tabular}{r|}
23.7 \\
45.8 \\
10.2 \\
10.2 \\
10.2 \\
100.0
\end{tabular} & $\begin{array}{r}23.7 \\
45.8 \\
10.2 \\
10.2 \\
10.2 \\
100.0\end{array}$ & $\begin{array}{r}23.7 \\
69.5 \\
79.7 \\
89.8 \\
100.0\end{array}$ \\
\hline
\end{tabular}

Table 3: Frequency distributions of the items related to Communication Apprehension

\section{B. Test Anxiety:}

Another major aspect that Horwitz et. al. took into consideration while preparing the scale to measure anxiety, was Test Anxiety. Students don't feel quite comfortable when they are evaluated especially when the evaluation is open and errors are corrected in front of their peers. Error correction is an integral part of language classes and the errors made my learners are corrected by the teachers on regular basis sometimes in the open class and sometimes individually. In the Indian context, since English language has been associated with status and intelligence, students don't feel comfortable when their mistakes are pointed out or highlighted for correction.
The analysis of the data clearly suggests that students do have test anxiety (Ref. Table 4). Over $58 \%$ respondents agreed and strongly agreed that they feel scared of tests and whenever they are called to present in classrooms in English, they start to tremble with fear. It is interesting to see that no student strongly agreed and just $17 \%$ agreed to the statement that they don't get bothered if they have to attend more English language classes. This clearly means that almost all of them have some inhibitions to attend English language classes. The students even admit to be thinking about issues not related to the classes while they are in English language classes. More than $65 \%$ students have accepted that they are not focused in English classes. This could mean that perhaps they lack motivation to learn 
English and they are too anxious of their performance to stay focused. This is indeed a very serious problem that needs to be addressed by English teachers. If there is lack of motivation, teachers need to find ways to motivate the students to participate. It can be easily seen that oral presentations give the students jitters. Around $59 \%$ students disagreed and $12 \%$ strongly disagreed to the item "I usually feel at ease when I have oral presentation in the class in English." This indicates how terrified the students are of oral presentations in English class since they know their mistakes would be recorded and corrected. Over $62 \%$ students admit that their hearts start pounding when they are called to speak publicly in English. With all this anxiety that tends to pull back, the learners still wish to learn English language to be professionally ready to join good companies and they worry about not being able to learn English language. More than 33 $\%$ students strongly agree that they get worried about not being able to learn English and would fail to get good jobs in the corporate and an equal number of students agree to the statement. Almost $75 \%$ students agree or strongly agree that they even forget the things which they know when they are asked to speak publicly in English in the classes or otherwise.
The fear is basically of the evaluation by the teacher and the peers. $65 \%$ students also believe that they get anxious and nervous even when they are prepared when they are asked to speak publicly in English. The anxiety is to such a level that there are many students who even don't want to attend the language classes. Around $50 \%$ students feel like not going to English language classes. This is such a big concern that needs to be addressed by the language teachers as soon as possible. Students also admit that the grammar rules are many a times confusing for them and the more they study about these rules, the more confused they get. Around $65 \%$ students feel that they get confused by the rules of grammar of English. Perhaps all these are the reasons why students feel more anxious in English language classes. More than $65 \%$ respondents admit that they are more comfortable in other classes than English language class.

The fear and anxiety of evaluation and mistakes being highlighted is very strong and create inhibitions in English language learners. The students of B-Schools, the respondents in this study, do wish to be able to speak English fluently but perhaps the anxiety is too strong to let them do so.

\begin{tabular}{|c|c|c|c|c|c|}
\hline \multicolumn{6}{|c|}{ Anxiety3 } \\
\hline & & Frequency & Percent & Valid Percent & $\begin{array}{l}\text { Cumulative } \\
\text { Percent }\end{array}$ \\
\hline Valid & $\begin{array}{l}\text { Strongly Agree } \\
\text { Agree } \\
\text { Neutral } \\
\text { Disagree } \\
\text { Strongly Disagree } \\
\text { Total }\end{array}$ & $\begin{array}{r}12 \\
57 \\
26 \\
13 \\
10 \\
118\end{array}$ & $\begin{array}{r}10.2 \\
48.3 \\
22.0 \\
11.0 \\
8.5 \\
100.0\end{array}$ & \begin{tabular}{r|}
10.2 \\
48.3 \\
22.0 \\
11.0 \\
8.5 \\
100.0
\end{tabular} & $\begin{array}{r}10.2 \\
58.5 \\
80.5 \\
91.5 \\
100.0\end{array}$ \\
\hline \multicolumn{6}{|c|}{ Anxiety5 } \\
\hline Valid & $\begin{array}{l}\text { Strongly Agree } \\
\text { Agree } \\
\text { Neutral } \\
\text { Disagree } \\
\text { Strongly Disagree } \\
\text { Total }\end{array}$ & $\begin{array}{r}0 \\
17 \\
30 \\
47 \\
24 \\
118\end{array}$ & $\begin{array}{r}0.0 \\
14.4 \\
25.4 \\
39.8 \\
20.4 \\
100.0\end{array}$ & $\begin{array}{r}0.0 \\
14.4 \\
25.4 \\
39.8 \\
20.4 \\
100.0\end{array}$ & $\begin{array}{r}0.0 \\
14.4 \\
39.8 \\
79.6 \\
100.0\end{array}$ \\
\hline \multicolumn{6}{|c|}{ Anxiety6 } \\
\hline Valid & $\begin{array}{l}\text { Strongly Agree } \\
\text { Agree } \\
\text { Neutral } \\
\text { Disagree } \\
\text { Strongly Disagree } \\
\text { Total }\end{array}$ & $\begin{array}{r}27 \\
50 \\
11 \\
29 \\
1 \\
118\end{array}$ & $\begin{array}{r}22.9 \\
42.4 \\
9.3 \\
24.6 \\
.8 \\
100.0\end{array}$ & $\begin{array}{r}22.9 \\
42.4 \\
9.3 \\
24.6 \\
.8 \\
100.0\end{array}$ & $\begin{array}{r}22.9 \\
65.3 \\
74.6 \\
99.2 \\
100.0\end{array}$ \\
\hline \multicolumn{6}{|c|}{ Anxiety8 } \\
\hline
\end{tabular}


English Language Anxiety and its impact on the Communicative Performance of the Learners w.r.t the Students of B-Schools in Delhi NCR, India

\begin{tabular}{|c|c|c|c|c|c|}
\hline Valid & $\begin{array}{l}\text { Strongly Agree } \\
\text { Agree } \\
\text { Neutral } \\
\text { Disagree } \\
\text { Strongly Disagree } \\
\text { Total }\end{array}$ & \begin{tabular}{r|}
0 \\
8 \\
26 \\
70 \\
14 \\
118
\end{tabular} & $\begin{array}{r}0 \\
6.8 \\
22 \\
59.3 \\
11.9 \\
100.0\end{array}$ & $\begin{array}{r}0 \\
6.8 \\
22 \\
59.3 \\
11.9 \\
100.0\end{array}$ & $\begin{array}{r}0 \\
6.8 \\
28.8 \\
88.1 \\
100.0\end{array}$ \\
\hline \multicolumn{6}{|c|}{ Anxiety10 } \\
\hline Valid & $\begin{array}{l}\text { Strongly Agree } \\
\text { Agree } \\
\text { Neutral } \\
\text { Disagree } \\
\text { Strongly Disagree } \\
\text { Total }\end{array}$ & \begin{tabular}{r|}
39 \\
39 \\
25 \\
10 \\
5 \\
118
\end{tabular} & \begin{tabular}{r|r|}
33.1 & 33.1 \\
21.2 & 8.5 \\
4.2 & \\
100.0 &
\end{tabular} & \begin{tabular}{r|r|}
33.1 & 33.1 \\
21.2 & 8.5 \\
4.2 & \\
100.0 &
\end{tabular} & $\begin{array}{r}33.1 \\
66.2 \\
87.4 \\
95.8 \\
100.0\end{array}$ \\
\hline \multicolumn{6}{|c|}{ Anxiety11 } \\
\hline Valid & $\begin{array}{l}\text { Strongly Agree } \\
\text { Agree } \\
\text { Neutral } \\
\text { Disagree } \\
\text { Strongly Disagree } \\
\text { Total }\end{array}$ & \begin{tabular}{r|}
1 \\
12 \\
23 \\
39 \\
43 \\
118
\end{tabular} & \begin{tabular}{r|}
.8 \\
10.2 \\
19.5 \\
33.1 \\
36.4 \\
100.0
\end{tabular} & \begin{tabular}{r|r}
.8 \\
10.2 \\
19.5 \\
33.1 \\
36.4 \\
100.0
\end{tabular} & $\begin{array}{r}.8 \\
20.0 \\
39.5 \\
72.6 \\
100.0\end{array}$ \\
\hline \multicolumn{6}{|c|}{ Anxiety12 } \\
\hline Valid & $\begin{array}{l}\text { Strongly Agree } \\
\text { Agree } \\
\text { Neutral } \\
\text { Disagree } \\
\text { Strongly Disagree } \\
\text { Total }\end{array}$ & \begin{tabular}{r|}
36 \\
52 \\
12 \\
11 \\
7 \\
118
\end{tabular} & $\begin{array}{r}30.5 \\
44.1 \\
10.2 \\
9.3 \\
5.9 \\
100.0\end{array}$ & $\begin{array}{r}30.5 \\
44.1 \\
10.2 \\
9.3 \\
5.9 \\
100.0\end{array}$ & $\begin{array}{r}30.5 \\
74.6 \\
84.7 \\
94.1 \\
100.0\end{array}$ \\
\hline \multicolumn{6}{|c|}{ Anxiety16 } \\
\hline Valid & $\begin{array}{l}\text { Strongly Agree } \\
\text { Agree } \\
\text { Neutral } \\
\text { Disagree } \\
\text { Strongly Disagree } \\
\text { Total }\end{array}$ & \begin{tabular}{r|}
33 \\
44 \\
12 \\
18 \\
11 \\
118
\end{tabular} & \begin{tabular}{r|}
28.0 \\
37.3 \\
10.2 \\
15.3 \\
9.3 \\
100.0
\end{tabular} & \begin{tabular}{r|}
28.0 \\
37.3 \\
10.2 \\
15.3 \\
9.3 \\
100.0
\end{tabular} & $\begin{array}{r}28.0 \\
65.3 \\
75.4 \\
90.7 \\
100.0\end{array}$ \\
\hline \multicolumn{6}{|c|}{ Anxiety17 } \\
\hline Valid & $\begin{array}{l}\text { Strongly Agree } \\
\text { Agree } \\
\text { Neutral } \\
\text { Disagree } \\
\text { Strongly Disagree } \\
\text { Total }\end{array}$ & $\begin{array}{r}15 \\
44 \\
21 \\
23 \\
15 \\
118\end{array}$ & \begin{tabular}{r|r}
12.7 \\
37.3 \\
17.8 \\
19.5 \\
12.7 \\
100.0
\end{tabular} & \begin{tabular}{r|r}
12.7 & 37.3 \\
17.8 \\
19.5 \\
12.7 \\
100.0
\end{tabular} & $\begin{array}{r}12.7 \\
50.0 \\
67.8 \\
87.3 \\
100.0\end{array}$ \\
\hline
\end{tabular}




\begin{tabular}{|c|c|c|c|c|c|}
\hline Valid & $\begin{array}{l}\text { Strongly Agree } \\
\text { Agree } \\
\text { Neutral } \\
\text { Disagree } \\
\text { Strongly Disagree } \\
\text { Total }\end{array}$ & $\begin{array}{r}12 \\
61 \\
24 \\
13 \\
7 \\
118\end{array}$ & \begin{tabular}{r|}
11.0 \\
51.7 \\
20.3 \\
11.0 \\
5.9 \\
100.0
\end{tabular} & $\begin{array}{r}11.0 \\
51.7 \\
20.3 \\
11.0 \\
5.9 \\
100.0\end{array}$ & $\begin{array}{r}11.0 \\
62.7 \\
83.1 \\
94.1 \\
100.0\end{array}$ \\
\hline \multicolumn{6}{|c|}{ Anxiety21 } \\
\hline Valid & $\begin{array}{l}\text { Strongly Agree } \\
\text { Agree } \\
\text { Neutral } \\
\text { Disagree } \\
\text { Strongly Disagree } \\
\text { Total }\end{array}$ & \begin{tabular}{r|}
33 \\
44 \\
12 \\
18 \\
11 \\
118
\end{tabular} & \begin{tabular}{r|}
28.0 \\
37.3 \\
10.2 \\
15.3 \\
9.3 \\
100.0
\end{tabular} & $\begin{array}{r}28.0 \\
37.3 \\
10.2 \\
15.3 \\
9.3 \\
100.0\end{array}$ & $\begin{array}{r}\mathbf{2 8 . 0} \\
\mathbf{6 5 . 3} \\
\mathbf{7 5 . 4} \\
\mathbf{9 0 . 7} \\
\mathbf{1 0 0 . 0}\end{array}$ \\
\hline \multicolumn{6}{|c|}{ Anxiety 22} \\
\hline Valid & $\begin{array}{l}\text { Strongly Agree } \\
\text { Agree } \\
\text { Neutral } \\
\text { Disagree } \\
\text { Strongly Disagree } \\
\text { Total }\end{array}$ & $\begin{array}{r}33 \\
44 \\
12 \\
18 \\
11 \\
118\end{array}$ & \begin{tabular}{r|}
28.0 \\
37.3 \\
10.2 \\
15.3 \\
9.3 \\
100.0
\end{tabular} & $\begin{array}{r}28.0 \\
37.3 \\
10.2 \\
15.3 \\
9.3 \\
100.0\end{array}$ & $\begin{array}{r}28.0 \\
65.3 \\
75.4 \\
90.7 \\
100.0\end{array}$ \\
\hline \multicolumn{6}{|c|}{ Anxiety 25} \\
\hline Valid & $\begin{array}{l}\text { Strongly Agree } \\
\text { Agree } \\
\text { Neutral } \\
\text { Disagree } \\
\text { Strongly Disagree } \\
\text { Total }\end{array}$ & $\begin{array}{r}33 \\
44 \\
12 \\
18 \\
11 \\
118\end{array}$ & \begin{tabular}{r|}
28.0 \\
37.3 \\
10.2 \\
15.3 \\
9.3 \\
100.0
\end{tabular} & $\begin{array}{r}28.0 \\
37.3 \\
10.2 \\
15.3 \\
9.3 \\
100.0\end{array}$ & $\begin{array}{r}28.0 \\
65.3 \\
75.4 \\
90.7 \\
100.0\end{array}$ \\
\hline \multicolumn{6}{|c|}{ Anxiety26 } \\
\hline Valid & $\begin{array}{l}\text { Strongly Agree } \\
\text { Agree } \\
\text { Neutral } \\
\text { Disagree } \\
\text { Strongly Disagree } \\
\text { Total }\end{array}$ & \begin{tabular}{r|r|}
33 & 44 \\
12 \\
18 \\
18 \\
11 \\
118
\end{tabular} & \begin{tabular}{r|}
28.0 \\
37.3 \\
10.2 \\
15.3 \\
9.3 \\
100.0
\end{tabular} & $\begin{array}{r}28.0 \\
37.3 \\
10.2 \\
15.3 \\
9.3 \\
100.0\end{array}$ & $\begin{array}{r}28.0 \\
65.3 \\
75.4 \\
90.7 \\
100.0\end{array}$ \\
\hline
\end{tabular}

Table 4: Frequency distributions of the items related to Test Anxiety

\section{B. Social Evaluation:}

In the Indian context, English language, in addition to being important for jobs, is also associated with status and intelligence. People who speak good English are considered more educated and more intelligent. Such people are considered high-class whereas those who are not able to speak fluently are considered gaunt. this, by no means is true, but this is how the people think in India. therefore, English language anxiety has one more very major factor that affects it and that is Social Evaluation. People who speak in English publicly are always conscious of the fact that they are being evaluated by the listeners socially also. This awareness makes them anxious. Learners who are trying to learn this language face the same problem. Whenever they speak in English publicly in the classrooms, they feel that they are also being evaluated and judged socially. They get scared and anxious when their mistakes are pointed out by the teachers. The fear is of social evaluation. If they make mistakes in speaking English, the peers might take the speaker to be from educationally backward family or background. This fear creates a lot of anxiety in the students.

Looking at the results of the items related to investigating Anxiety because of social evaluation (Ref. Table 5), one can easily find out that students are anxious to learn English as a second language. More than $38 \%$ students disagree and another $21 \%$ strongly disagree that they don't worry about making mistakes in the classroom. It means that around $59 \%$ students do worry about making mistakes and being exposed as not capable of speaking English. Anxiety due to potential social evaluation is so strong that almost $64 \%$ students admit that they keep comparing themselves with others in the language class. Almost $67 \%$ students believe that their counterparts speak better English than themselves. The learners perhaps don't want to be labelled as 'gaunt'. The 
students even fear to volunteer in the language classes because of the apprehension of being judged socially. A whopping $73 \%$ students keep quiet when the teachers ask for volunteers in English language classes. The basic fear is of being judged socially if they make mistakes while speaking in English. Around $63 \%$ respondents are afraid of the teacher finding their mistakes and correcting them publicly.
Social Evaluation is a very strong factor that results in language learning anxiety. Especially in the Indian context, this factor is even stronger since English language is a status symbol here and nobody wants to be evaluated otherwise socially.

\begin{tabular}{|c|c|c|c|c|c|}
\hline & & Frequency & Percent & $\begin{array}{l}\text { Valid } \\
\text { Percent }\end{array}$ & $\begin{array}{l}\text { Cumulative } \\
\text { Percent }\end{array}$ \\
\hline \multicolumn{6}{|c|}{ Anxiety2 } \\
\hline Valid & $\begin{array}{l}\text { Strongly Agree } \\
\text { Agree } \\
\text { Neutral } \\
\text { Disagree } \\
\text { Strongly Disagree } \\
\text { Total }\end{array}$ & $\begin{array}{r}9 \\
20 \\
19 \\
45 \\
25 \\
118\end{array}$ & $\begin{array}{r}7.6 \\
16.9 \\
16.1 \\
38.1 \\
21.3 \\
100.0\end{array}$ & $\begin{array}{r}7.6 \\
16.9 \\
16.1 \\
38.1 \\
21.3 \\
100.0\end{array}$ & $\begin{array}{r}7.6 \\
24.5 \\
40.6 \\
78.7 \\
100.0\end{array}$ \\
\hline \multicolumn{6}{|c|}{ Anxiety7 } \\
\hline Valid & $\begin{array}{l}\text { Strongly Agree } \\
\text { Agree } \\
\text { Neutral } \\
\text { Disagree } \\
\text { Strongly Disagree } \\
\text { Total }\end{array}$ & $\begin{array}{r}35 \\
40 \\
15 \\
16 \\
12 \\
118\end{array}$ & $\begin{array}{r}29.7 \\
33.9 \\
12.7 \\
13.6 \\
10.2 \\
100.0\end{array}$ & $\begin{array}{r}29.7 \\
33.9 \\
12.7 \\
13.6 \\
10.2 \\
100.0\end{array}$ & $\begin{array}{r}29.7 \\
63.6 \\
76.3 \\
89.8 \\
100.0\end{array}$ \\
\hline \multicolumn{6}{|c|}{ Anxiety13 } \\
\hline Valid & $\begin{array}{l}\text { Strongly Agree } \\
\text { Agree } \\
\text { Neutral } \\
\text { Disagree } \\
\text { Strongly Disagree } \\
\text { Total }\end{array}$ & $\begin{array}{r}42 \\
44 \\
12 \\
10 \\
10 \\
118\end{array}$ & $\begin{array}{r}35.6 \\
37.3 \\
10.2 \\
8.5 \\
8.5 \\
100.0\end{array}$ & $\begin{array}{r}35.6 \\
37.3 \\
10.2 \\
8.5 \\
8.5 \\
100.0\end{array}$ & $\begin{array}{r}35.6 \\
72.9 \\
83.1 \\
91.5 \\
100.0\end{array}$ \\
\hline \multicolumn{6}{|c|}{ Anxiety19 } \\
\hline Valid & $\begin{array}{l}\text { Strongly Agree } \\
\text { Agree } \\
\text { Neutral } \\
\text { Disagree } \\
\text { Strongly Disagree } \\
\text { Total }\end{array}$ & \begin{tabular}{r|}
36 \\
38 \\
9 \\
23 \\
12 \\
118
\end{tabular} & $\begin{array}{r}30.5 \\
32.2 \\
7.6 \\
19.5 \\
10.2 \\
100.0\end{array}$ & $\begin{array}{r}30.5 \\
32.2 \\
7.6 \\
19.5 \\
10.2 \\
100.0\end{array}$ & $\begin{array}{r}30.5 \\
62.7 \\
70.3 \\
89.8 \\
100.0\end{array}$ \\
\hline \multicolumn{6}{|c|}{ Anxiety 23 } \\
\hline Valid & $\begin{array}{l}\text { Strongly Agree } \\
\text { Agree } \\
\text { Neutral } \\
\text { Disagree } \\
\text { Strongly Disagree } \\
\text { Total }\end{array}$ & $\begin{array}{l}22 \\
56 \\
13 \\
27 \\
118\end{array}$ & $\begin{array}{l}18.6 \\
47.5 \\
11.0 \\
22.9 \\
100.0\end{array}$ & $\begin{array}{l}18.6 \\
47.5 \\
11.0 \\
22.9 \\
100.0\end{array}$ & \begin{tabular}{|l}
18.6 \\
66.1 \\
77.1 \\
100.0
\end{tabular} \\
\hline
\end{tabular}

Table 5: Frequency distributions of the items related to Social Evaluation

\section{CONCLUSION}

The study was conducted to analyze and investigate the impact of language learning anxiety of the PG level students of Business Schools in Delhi NCR (National Capital Region) on their communicative performance especially considering the impact on the oral performance of the learners while learning English as the second language. The aim was at finding whether the classroom anxiety affected the communicative performance of learners or not. The study took into consideration the three major factors highlighted by 
Horwitz et. al. while constructing the Foreign Language Classroom Anxiety Scale (FLCAS) namely Communication Apprehension; Test Anxiety; and Fear of social evaluation.

The management graduates - PGDM (Post Graduate Diploma in Management) were the target of the study. The well perceived utility of English language in helping the B-School graduates in getting good jobs was the major attribute identified by means of the study. For these management students good proficiency in English is very important to help them get good jobs in the corporate and then to sustain the employment. The institutes, as well as, the students are putting up efforts to improve English language communication of the would-be managers but still the students are not able to learn English language in a standard way. Most of these students study English language courses and communication courses throughout their schools and colleges but still they are not able to acquire good proficiency in English language. One very major factor for this problem is English Language Anxiety the students experience when they start to learn English as a second language. The present study aimed at analysing this anxiety and see how language anxiety impacts the communicative performance of these students.

On the basis of the analysis and subsequent discussion, it can be stated that Language Learning Anxiety is indeed a very strong factor that affects directly the communicative performance of the students. The students were very apprehensive about expressing themselves clearly in English because they don't get exposure to this language much and they are not sure if they speak English correctly. The respondents displayed apprehension of tests and evaluation. They admitted that they were scared to be evaluated and felt uncomfortable when corrected by the language teachers. This fear of evaluation made them anxious whenever they were asked to speak or present in English language in the classes. They were also scared of social evaluation. Since, in India English language has become a status symbol, wrongly though, students were afraid of being considered low-class by the peers just because they can't speak fluent and correct English. English language, in India, has wrongly become a measure of intelligence and that is why the students were afraid of being evaluated and corrected in front of other students. They were scared that wrong usage of English language would make them look less educated and less intelligent.

The Anxiety resulting from the factors like tests, social evaluation and communication apprehension is indeed very strong. This anxiety directly affects the communicative performance of the students especially the oral performance. Students are afraid of speaking publicly. Whenever these students are asked or called to speak publicly in english, they get terrified and anxious. The anxiety makes them forget even the things that they otherwise know. These students may be reasonable good at writing in English but when it comes to speaking, they get anxious to core. Anxiety does affect written communicative performance of the students since they fear the evaluation but oral performance is something that makes their hearts go pounding.

In order to help these students learn English in a proper and standard way, teachers need to first find out ways to motivate

them and help them get rid of anxiety. A lot of orientation is required to make these students understand that English is just another language which is used to communicate. It has, however, become very important because of reasons known to everybody.

\section{LIMITATIONS:}

The major limitation of the present study could be the scale itself which can be distorted by various causes. The respondents might not record responses in an objective way making the analysis skewed. The respondents may be biased or may exercise acquiescence bias wherein they may either disagree or agree with almost all the statements without reading through the statement objectively. The respondents may choose only positive statements in order to portray themselves in favourable light. While analysing any data collected the researchers assume that the respondents have responded very honestly and objectively; however, there is always a chance that the items in the questionnaires are sometimes, no matter how well phrased, tend to skew down the results by making some respondents "flatter themselves," or to "appease what they may perceive as an unseen authority behind the questionnaire" (Hashimoto, 2002, p. 35).

\section{REFERENCES:}

1. Aida, Y. (1994). Examination of Horwitz, Horwitz, and Cope's construct of foreign language anxiety: The case of students of Japanese. The modern language journal, 78(2), 155-168.

2. Bailey, K. M. (1983). Competitiveness and anxiety in adult second language learning: Looking at and through the diary studies. Classroom oriented research in second language acquisition, 67-102.

3. Brown, H. D. (2000). Principles of language learning and teaching.

4. Burns, A. (2000). Genre and genre-based teaching. In Routledge encyclopedia of language teaching and learning (pp. 234-238). Routledge, Taylor and Francis Group.

5. Dictionary, M. W. (2002). Merriam-Webster. On-line at http://www. mw. com/home. htm.

6. Frantzen, D., \& Magnan, S. S. (2005). Anxiety and the true beginner-false beginner dynamic in beginning French and Spanish classes. Foreign Language Annals, 38(2), 171-186.

7. Gregersen, T. S. (2003). To err is human: A reminder to teachers of language-anxious students. Foreign Language Annals, 36(1), 25-32.

8. Hashimoto, Y. (2002). Motivation and willingness to communicate as predictors of reported L2 use: The Japanese ESL context. Second language studies, 20(2), 29-70.

9. Horwitz, E. K. (2010). Foreign and second language anxiety. Language Teaching, 43(2), 154-167.

10. Horwitz, E. K., Horwitz, M. B., \& Cope, J. (1986). Foreign language classroom anxiety. The Modern language journal, 70(2), 125-132.

11. Horwitz, E. K. (1986). Preliminary evidence for the reliability and validity of a foreign language anxiety scale. Tesol Quarterly, 20(3), 559-562.

12. https://en.wikipedia.org/wiki/Languages with official status in Indi a\#Official languages of the Union

13. MacIntyre, P. D. (1999). Language anxiety: A review of the research for language teachers. Affect in foreign language and second language learning: A practical guide to creating a low-anxiety classroom atmosphere, 24, 41.

14. MacIntyre, P. D., \& Gardner, R. C. (1991). Investigating language class anxiety using the focused essay technique. The Modern Language Journal, 75(3), 296-304.

15. Masani, Z. (2012). English or Hinglish-Which will India choose. BBC News, 27.

16. Campbell, C. M., \& Ortiz, J. (1991). Helping students overcome foreign language anxiety: A foreign language anxiety workshop. Language anxiety: From theory and research to classroom implications, 153-168. 
17. Paee, R. B., \& Misieng, J. (2012). Foreign Language Classroom Anxiety Scale: A Comparison of Three Models. Universiti Malaysia Sarawak.

18. Phillips, E. M. (1992). The effects of language anxiety on students' oral test performance and attitudes. The modern language journal, 76(1), $14-26$

19. Saito, Y., \& Samimy, K. K. (1996). Foreign language anxiety and language performance: A study of learner anxiety in beginning, intermediate, and advanced-level college students of Japanese. Foreign Language Annals, 29(2), 239-249.

20. Spielmann, G., \& Radnofsky, M. L. (2001). Learning language under tension: New directions from a qualitative study. The Modern Language Journal, 85(2), 259-278.

21. Na, Z. (2007). A study of high school students' English learning anxiety. The Asian EFL Journal, 9(3), 22-34. 